\title{
Identifying safe drinking water source for establishing sustainable urban water supply scheme in Rangunia municipality, Bangladesh
}

\author{
$\underline{\text { S.K. Adhikary }}{ }^{\text {a }}$, S.K. Das ${ }^{\text {a }}$, T. Chaki ${ }^{\text {b }}$ and M. Rahman ${ }^{\text {b }}$ \\ ${ }^{a}$ College of Engineering and Science, Victoria University, Melbourne 14428, Victoria 8001, Australia \\ ${ }^{b}$ Water Resources Planning Division, Institute of Water Modelling (IWM), Dhaka 1206, Bangladesh \\ Email:sajal.adhikary@,live.vu.edu.au
}

\begin{abstract}
Safe drinking water source identification is one of the vital components for designing and establishing an urban water supply system. Nowadays, water consumption in a country is one of the determining factors related to its development activities. Rapid growth of population and increased urbanization activities particularly in developing countries offer great challenges to the water utility managers and service providers. In this context, a major challenge is to ensure adequate supply of water with acceptable quality to every city dwellers with minimum cost. However, it is quite difficult to achieve this target, if there is a shortage in water availability from the existing sources imposed by water quantity and quality issues. Therefore, a comprehensive assessment task should be undertaken prior to designing and establishing a long-term water supply options in an urban area of a developing country like Bangladesh.
\end{abstract}

In Bangladesh, municipal water supply scheme mainly depends on the conventional water sources such as surface water from the rivers and groundwater from the underlying aquifer. Although the groundwater quality is satisfactory for drinking purpose and available abundantly in the shallow aquifer, quality limitations of surface water impose economic constraints with additional treatment cost for system operation. Nevertheless, water availability in both sources may vary from place to place, and must be quantified before any planning and development of water supply scheme. Hence, this study attempts to identify appropriate conventional water sources by mathematical modelling as an assessment case study before establishing a sustainable urban water supply scheme at Rangunia municipality in Bangladesh, where there is no water supply system at present.

Water demand in the Rangunia municipality is estimated up to the design year of 2040 based on the available population census data. Based on the regional model assessment results, suitability of surface water and groundwater sources against the existing and projected water demand has been evaluated. The Eastern Hill Region Model (EHRM) developed and maintained by the Institute of Water Modelling (IWM), Bangladesh is used for surface water source assessment. The flow simulation in the EHRM has been carried out by using MIKE-11 software. For developing groundwater model, the hydrogeological setting and aquifer demarcation in the municipality area is accomplished by analyzing the individual hydrostratigraphic sections produced from the borehole lithology. The groundwater model domain covers a larger area $(4574 \mathrm{sq} . \mathrm{km}$.) to avoid the boundary influence in model computation, which includes the study municipality (13.34 sq. km.). Therefore, the developed groundwater model of the study area spreads over 22 upazillas (sub-districts) of Chittagong, Rangamati and Khagrachhari districts in the eastern part of Bangladesh. Groundwater simulation is carried out in an integrated MIKE-11 and MIKE-SHE software platform.

The simulation results along with measured water quality parameters indicate that none of the surface water and groundwater source is suitable for long-term water supply option in Rangunia municipality even though adequate quantity of water is available from both sources. Surface water source is highly associated with water quality issues based on Bangladesh drinking water standard, whereas groundwater level shows a decline trend on long-term exploitation. Therefore, the present study concludes that upon having a suitable treatment of surface water, existing surface water and/or groundwater sources can be used as safe drinking water sources for developing sustainable water supply scheme in Rangunia municipality of Bangladesh.

Keywords: $\quad$ Mathematical modelling, Rangunia municipality, EHRM, Urban water supply, Conventional water source 
Adhikary et al., Identifying safe drinking water source for establishing sustainable urban water supply scheme in Rangunia municipality, Bangladesh

\section{INTRODUCTION}

Identification and establishment of safe and sustainable water source is one of the important components for designing any urban water supply scheme. Adequate water supply with acceptable quality is the most challenging task to the urban development authorities in developing countries, which is a necessary obligation and important concern for sustainable urban development (Karim and Mohsin, 2009). Nowadays, the development activities in a country are very relevant to its water consumption characteristics. The problem is more critical particularly in the urban segment of a country (Garcia et al., 2008). United Nations predicted that about $56 \%$ of the people in the developing countries would be resided in urban areas in the next decades. Likewise, urban population is increasing rapidly in Bangladesh because of its natural urban growth and migration from rural areas (Karim and Mohsin, 2009). An estimation by the Bangladesh Bureau of Statistics (BBS) shows that the urban population in the country was about 38 million in 2005, and expected to be doubled by 2035 (BBS, 2005). Such growth of urban population will certainly add a remarkable burden on the country's target of providing safe water supply and adequate sanitation facilities. As a consequence, this fact has put an obligation to establish an appropriate management policy that can ensure continuity of water supply to the urban dwellers while maintaining the development activities. It is also highlighted in the national water policy in Bangladesh, which states that all sorts of required means and measures should be taken to manage water resources of the country in a comprehensive, integrated and equitable manner (WaRPO, 1999).

Water management in an area should be based on the appropriate knowledge of available surface water (SW) and groundwater (GW) systems (Garcia et al., 2008). In Bangladesh, municipal water supply system mainly depends on the conventional water sources such as the SW and GW systems. However, water quantity and quality limitations of these sources often impose economic constraints on the system operation requiring additional treatment costs including development of more expensive alternative sources in the system (Shah and Khan, 2008). According to Dasgupta et al. (2005), most of the SW sources in Bangladesh is usually polluted and requires treatment prior to consumption. Thus, management of urban water supply systems becomes difficult if there is a shortfall in water availability from the sources constrained by water quantity and quality limitations. Therefore, identification and establishment of safe drinking water source is a major challenging task in a developing country like Bangladesh. The overall objective of this study is the assessment of existing SW and GW sources for identifying the safe water source in order to establish longterm water supply options in the Rangunia municipality under Chittagong district in Bangladesh.

\section{THE STUDY AREA}

The present study concentrates on the Rangunia municipality as shown in Figure 1, which is the only urban area in Rangunia upazilla (sub-district) under Chittagong district in Bangladesh. It is situated on the banks of the Karnafuli River in the Eastern Hilly Region of Bangladesh. The municipality covers an area of about 13.34 sq. $\mathrm{km}$. Its population has been increasing since its inception. It is located at $38 \mathrm{~km}$. eastward from the Chittagong district headquarters under Chittagong division, consisting of nine wards. Although the relative importance of the municipality has ever been growing as a regional centre of trade and commerce, it has no piped water supply facilities at present. The municipal authority is now working on establishing

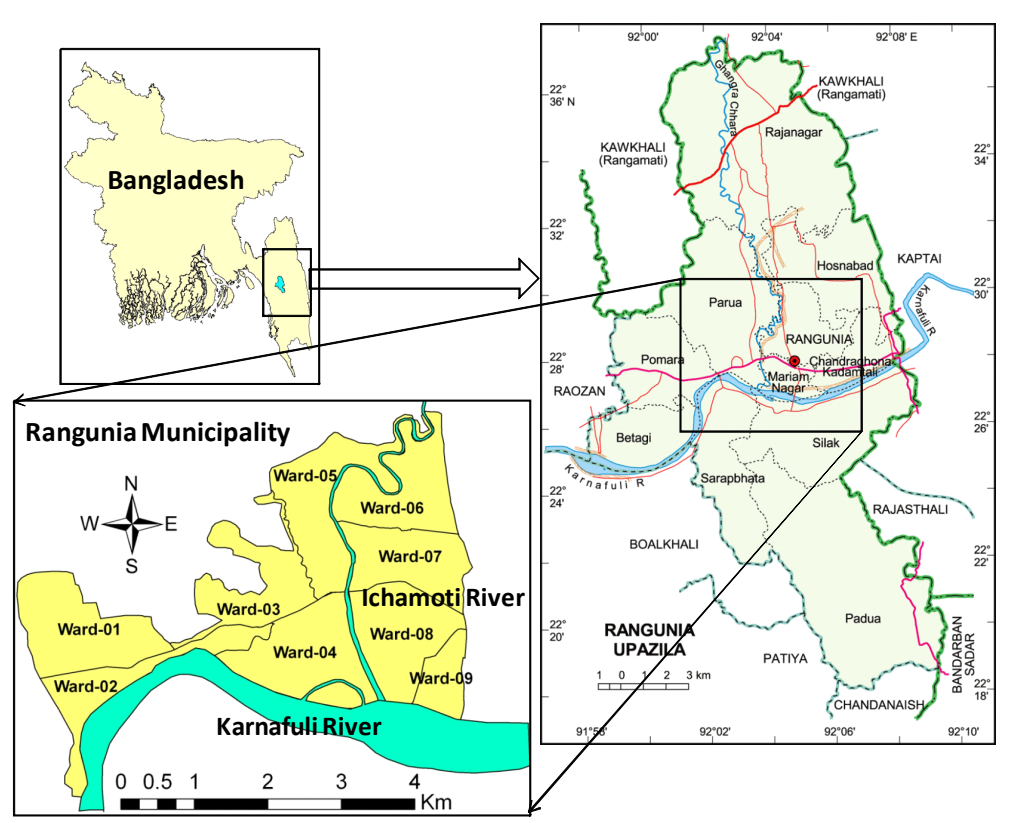

Figure 1. Location of the Rangunia municipality water distribution system. The municipality was established in 2000, and it is now classified as a 'B-class' municipality. Therefore, a detailed water resources assessment study has been undertaken prior to establishing the proposed water distribution networks. 
Adhikary et al., Identifying safe drinking water source for establishing sustainable urban water supply scheme in Rangunia municipality, Bangladesh

\section{ESTIMATION OF WATER DEMAND}

A widespread water demand assessment is performed in this study for the baseline year 2010, and is projected up to the design year 2040. The demand assessment technique includes both spatial and non-spatial information. GIS-based spatial maps and demographic characteristics of the study area are used in this study. GIS maps are prepared based on the topographic survey data conducted by Institute of Water Modelling (IWM) in 2010. However, demographic information are collected from the population census reports of BBS for the years 1981, 1991 and 2001. For the baseline year 2010, demographic data are obtained from the social impact assessment (SIA) survey. The population projection in the municipality is then accomplished, and per capita water demand for this growing municipality is assigned to the population in the municipality area. The water required for backwashing of the water treatment plant (WTP) has been added to the domestic water demand in order to estimate the final water demand. IWM has taken the backwash water as a per cent of water demand in their demand estimation method. This technique is repeated for every five years from 2010 to 2040, and the findings are presented in Table 1.

Table 1. Projected attributes of Rangunia municipality in Bangladesh

\begin{tabular}{lccccccc}
\hline \multirow{2}{*}{ Description of attributes } & \multicolumn{5}{c}{ Year } \\
\cline { 2 - 7 } & 2010 & 2015 & 2020 & 2025 & 2030 & 2035 & 2040 \\
\hline Population (nos.) & 36,270 & 40,432 & 45,219 & 51,949 & 58,497 & 68,035 & 77,166 \\
Water demand $\left(\mathrm{m}^{3} / \mathrm{d}\right)$ & 829 & 1,208 & 1,725 & 2,727 & 4,078 & 6,117 & 8,791 \\
Water demand + WTP backwash $\left(\mathrm{m}^{3} / \mathrm{d}\right)$ & 874 & 1277 & 1,829 & 2,901 & 4,352 & 6,549 & 9,443 \\
\hline
\end{tabular}

\section{ASSESSMENT OF SURFACE WATER SOURCE}

\subsection{EHRM Regional Model}

Six regional models have been developed and maintained by IWM, Bangladesh which cover the whole country, namely Southwest Regional Model, Northwest Regional Model, North Central Regional Model, Northeastern Regional Model, Southeastern Regional Model and Eastern Hill Regional Model. Rangunia municipality is situated on the banks of the Karnafuli River in the Eastern Hilly Region of Bangladesh. Assessment of available SW for Rangunia municipality water supply has been carried out from potential sources of nearby Karnafuli River using the Eastern Hill Regional Model (EHRM). The Karnafuli River flows from the Lusai hill of Mijoram state in India to the Bay of Bengal. This is mainly a perennial river influenced by tidal effect. Salinity level in the river near Rangunia municipality is low (3mg/L: Table 3) due to enough fresh water flows from the uphill. The EHRM covers an area of around 18,722 sq. km. spanning between longitudes $91^{\circ} 20^{\prime} \mathrm{E}$ to $92^{\circ} 43^{\prime} \mathrm{E}$ and latitudes $20^{\circ} 44^{\prime} \mathrm{N}$ to $23^{\circ} 44^{\prime} \mathrm{N}$. The four river basins within EHRM are the Karnafuli-Halda-Ichamati River basin, the Sangu River basin, the Matamuhuri River basin, and the Bank Khali River basin that cover an area of approximately 8,831 sq. km featuring predominantly hilly terrain and foothills, and a long strip of lowland coastal plains along the Bay of Bengal. Since flood forecasting and warning center (FFWC) is not concerned about the Bank Khali River system, it has been excluded from the EHRM domain. Besides the river systems in the three basins, there are numerous small streams (locally called as Chara), which drains out to the foothills on the east of Chittagong-Cox's Bazar highway and finally towards the sea.

The Karnafuli-Halda River sub-model (part of EHRM) was developed in 1993 using MIKE-11 with one year data of 1990, and has been updated for 1994-95 hydrological years. This model was again validated for $1995-$ 96, 1996-97 and 1997-98 hydrological years under the annual validation of all the regional models for National Water Management Plan (NWMP) project of the Water Resources Planning Organization (WaRPO). After implementing the mathematical model-based forecasting in all flood prone areas by FFWC, the updating and validation of EHRM had been conducted for hydrological year from 1998-99 to 2004-05. This study applies the modeling activities carried out in connection with updating and validation of the EHRM for 2005-06 hydrological year and monsoon 2006 period. The overall performance of the EHRM has remained consistently high over the years. A sample plot of calibrated water level (Station ID: Karnafuli 20000) near the Rangunia municipality on the Karnafuli River is presented in Figure 2a. Figure $2 \mathrm{~b}$ also shows the simulated discharge in the Karnafuli River on Ichamoti outfall (location ID: Karnafuli 19500).

\subsection{Appraisal of Surface Water Availability}

Assessment of SW availability for the water supply in Rangunia municipality is carried out from the longterm (comprising of 20-years model run) simulated discharge of validated model available at IWM. The assessment is done in terms of flow duration curve (FDC) prepared from simulated discharge data for year 
Adhikary et al., Identifying safe drinking water source for establishing sustainable urban water supply scheme in Rangunia municipality, Bangladesh

round discharge at Ichamati outfall point of the Karnfuli River. The discharge at any percentage of probability in FDC represents the flow magnitude in an average year that can be expected to be equalled or exceeded. Dependable flows have been computed for year round analyses for the period of 2004 to 2009 for Rangunia municipality and are presented in Table 2.
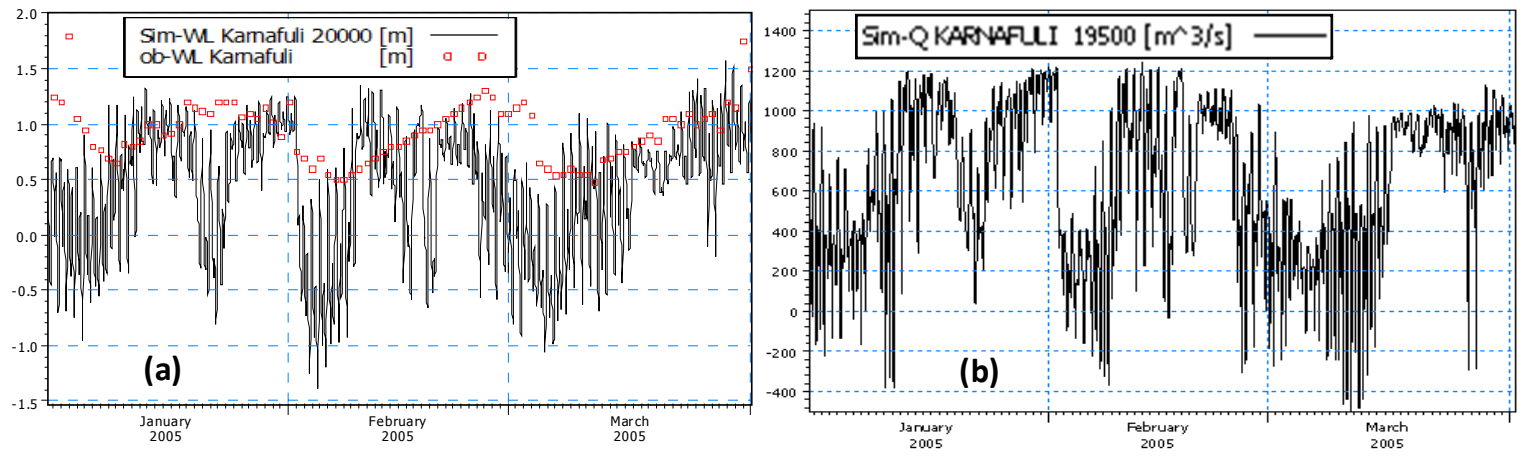

Figure 2. (a) Calibrated water level and (b) simulated discharge at the Karnafuli on Ichamati outfall

Table 2. Dependable flows for the Karnafuli River at Rangunia municipality

\begin{tabular}{ccccc}
\hline \multirow{2}{*}{ Location } & \multirow{2}{*}{ River } & \multicolumn{3}{c}{ Dependable flow for the dry season $\left(\mathrm{m}^{3} / \mathrm{s}\right)$} \\
\cline { 2 - 4 } & & $50 \%$ & $80 \%$ & $90 \%$ \\
\hline Rangunia & Karnafuli & 441.54 & 255.12 & 170.13 \\
\hline
\end{tabular}

In this study, Weibull method of flow duration curve (Chow et al., 1988) is adopted for dependable flow analysis. This method determines the desired value (i.e. dependable flow) by ranking the daily flows in descending order and assigning each with an exceedence probability. The simple plotting system is expressed by the Weibull plotting position formula as expressed by the Equation (1).

$$
P\left(X \geq x_{m}\right)=\frac{m}{n+1}
$$

Where, $P=$ the probability of excedence; $m=$ the rank number from 1 to $n$, where $n=$ the number of ranked flows. This method has been chosen over several available plotting position formulas in statistics (Chow et al., 1988) because of its simplicity and easy adaptability to computers. The water demand in Rangunia municipality along with the requirement of a water treatment plant (WTP) for its backwashing purpose has been estimated as $0.1093 \mathrm{~m}^{3} / \mathrm{s}\left(9443 \mathrm{~m}^{3} / \mathrm{d}\right)$ in the year 2040 . SW availability from Karnafuli River is estimated as $13,225,248 \mathrm{~m}^{3} / \mathrm{d}$. Moreover, Karnafuli River flows to the southern periphery of the municipality, where water is available round the year. From the analysis and findings, it appears that dependable flow in Karnafuli River can meet the water demand of Rangunia municipality round the year. Therefore, SW is sufficiently available to fulfill the water demand of the dwellers in Rangunia municipality under Chittagong district in Bangladesh and seems to be suitable source for longterm drinking water supply in terms of quantity aspect.

\begin{tabular}{|ll|}
\hline Box 1. Details calculation for dependable flow analysis & \\
Required SW withdrawal for water supply to Rangunia municipality & $=0.1093 \mathrm{~m}^{3} / \mathrm{s}$ \\
$80 \%$ dependable flow (from available water) of the Karnafuli River & $=255.12 \mathrm{~m}^{3} / \mathrm{s}$ \\
Available water in the Karnafuli River after withdrawal for water supply & $=255.01 \mathrm{~m}^{3} / \mathrm{s}$ \\
Exploitable flow ( $60 \%$ of $80 \%$ dependable flow) & $=153.07 \mathrm{~m}^{3} / \mathrm{s}$ \\
Environmental flow requirement (40\% of $80 \%$ dependable flow) & $=102.05 \mathrm{~m}^{3} / \mathrm{s}$ \\
Available SW resources for the dwellers in Rangunia municipality & $=13225248 \mathrm{~m}^{3} / \mathrm{d}$ \\
Water availability in the Karnafuli River & $=12 \mathrm{months}$ \\
\hline
\end{tabular}

\subsection{Evaluation of Surface Water Quality}

Water quality assessment (Table 3) has been carried out based on the primary water sampling data collection period at the selected locations on the Karnafuli River near Rangunia municipality. The first sampling mission was carried out in December 2011 (post-monsoon period) and laboratory testing was performed in Department of Public Health Engineering (DPHE) central lab, Dhaka. The test results indicate that only two parameters such as Biochemical Oxygen Demand $\left(\mathrm{BOD}_{5}\right)$ and Chemical Oxygen demand (COD) are not within allowable limit of Bangladesh drinking water standard (ECR, 1997). However, microbial test has not been performed yet. Therefore, Karnafuli River water can be taken as a safe drinking water source for municipal water supply in Rangunia municipality after appropriate treatment for BOD and COD, and the microbial parameters. 
Adhikary et al., Identifying safe drinking water source for establishing sustainable urban water supply scheme in Rangunia municipality, Bangladesh

Table 3. Surface water quality status of the Karnafuli River at Rangunia municipality

\begin{tabular}{cllcc}
\hline S1. No. & Parameter & Unit & Bangladesh Standard (ECR, 1997) & Measured Value in Post-monsoon \\
\hline 1 & $\mathrm{pH}$ & - & $6.5-8.5$ & 8.2 \\
2 & $\mathrm{BOD}_{5}$ & $\mathrm{mg} / \mathrm{L}$ & $\mathbf{0 . 2}$ & $\mathbf{2}$ \\
3 & $\mathrm{COD}$ & $\mathrm{mg} / \mathrm{L}$ & $\mathbf{4}$ & 0.56 \\
4 & Turbidity & $\mathrm{NTU}$ & 10 & 0.23 \\
5 & $\mathrm{NH}_{3}$ & $\mathrm{mg} / \mathrm{L}$ & 0.5 & 0.24 \\
6 & $\mathrm{NH}_{4}$ & $\mathrm{mg} / \mathrm{L}$ & 0.5 & 2 \\
7 & $\mathrm{NO}_{3}$ & $\mathrm{mg} / \mathrm{L}$ & 10 & 57 \\
9 & $\mathrm{TDS}$ & $\mathrm{mg} / \mathrm{L}$ & 1000 & 8 \\
10 & $\mathrm{TSS}_{11}$ & $\mathrm{mg} / \mathrm{L}$ & 10 & 0.95 \\
12 & $\mathrm{PO}$ & $\mathrm{mg} / \mathrm{L}$ & 6 & 0.002 \\
13 & $\mathrm{Cb}$ Total & $\mathrm{mg} / \mathrm{L}$ & 0.05 & 0.0031 \\
14 & $\mathrm{~Pb}$ & $\mathrm{mg} / \mathrm{L}$ & 0.05 & 3 \\
\hline
\end{tabular}

\section{ASSESSMENT OF GROUNDWATER SOURCE}

\subsection{Hydrogeological Setting and Aquifer Demarcation}

In this study, GW source assessment is performed based on two major tasks of hydrogeological studies, and GW modeling and simulation. Hydrogeological investigation has been carried out to define the hydrostratigraphic layers in Rangunia municipality. Sub-surface lithological characterization and formation of hydrostratigraphic units have been produced by analyzing the individual lithological units and depth of different aquifers from the available five lithological borelogs in the study area. Data analysis suggests that the aquifer is composed of fine sand with some medium sand. The columnar sections produced from borelogs indicate the top most clay layer varying in depth from place to place. Several hydrostratigraphic layers have been identified in the study area and are presented in Table 4. Analysis of aquifer properties indicate that the storage coefficient varies from 0.00112 to 0.00574 with an average value of 0.00379 . The transmissivity of the aquifer varies from 303 to $478 \mathrm{~m}^{2} /$ day having a mean value of $377.25 \mathrm{~m}^{2} /$ day. The storage coefficient, columnar section of borelogs and hydrostratigraphic sections indicate that the aquifer is semi confined in nature. By analyzing the stratigraphy of the study area, major hydrostratigraphic units are delineated accordingly and average thickness of individual hydrostratigraphic unit are presented in the Table 4.

Table 4. Summary of hydrostratigraphic units and their extents in Rangunia municipality

\begin{tabular}{lccc}
\hline \multirow{2}{*}{ Hydrostratigraphic Unit } & \multicolumn{2}{c}{ Depth $(\mathrm{m})$} & \multirow{2}{*}{ Thickness $(\mathrm{m})$} \\
\cline { 2 - 3 } & From & To & 8 \\
$1^{\text {st }}$ Aquiclude & 0 & 8 & 22 \\
$1^{\text {st }}$ Fine sand aquifer & 8 & 30 & 25 \\
$2^{\text {nd }}$ Aquiclude & 30 & 55 & 30 \\
$2^{\text {nd }}$ Fine sand aquifer & 55 & 85 & 15 \\
$3^{\text {rd }}$ Aquiclude & 85 & 100 & 10 \\
$3^{\text {rd }}$ Fine sand aquifer & 100 & 110 & 15 \\
$4^{\text {th }}$ Aquiclude & 110 & 125 & 35 \\
$4^{\text {th }}$ Fine sand aquiclude & 125 & 160 & 20 \\
$5^{\text {th }}$ Aquiclude & 160 & 180 & \\
\hline
\end{tabular}

\subsection{Simulation of the Groundwater System}

For GW source identification and resource assessment, large numbers of hydrogeological and meteorological (rainfall) data have been collected. For hydrogeological study and GW resource assessment, specific emphasis has been given for the municipality area and its vicinity at least the area of Rangunia municipality. For the GW modeling, a larger study area is normally considered to avoid the boundary influences in model computations (Anderson and Woessner, 1992). In this study, the model has been developed using MIKESHE (DHI, 1999) mathematical modeling software tool. MIKE-SHE is a comprehensive mathematical modeling system that covers the entire land-based hydrological cycle, simulating surface flow, infiltration, flow through the unsaturated zone (UZ), evapotranspiration and GW flow. It is designed to address dynamic exchange of the water between these components. Major components of the model setup include evapotranspiration, unsaturated zone, saturated zone, overland flow and river systems. The default time step control and computational control parameters for overland flow (OL), UZ and saturated zone (SZ) have been used for entire simulation period. However, simulation periods of the calibration, validation and prediction models were different and user specified. In this study, the model domain covers an area of about 4,574 sq. km., which includes 22 upazillas of Chittagong, Rangamati and Khagrachhari districts. 
Adhikary et al., Identifying safe drinking water source for establishing sustainable urban water supply scheme in Rangunia municipality, Bangladesh

The study area has been discredited into $1000 \mathrm{~m}$ square grids. The model has 4812 grid cells in each layer, where as 239 grids are the boundary cells and the rest are computational cells. The grid cells are the basic units to provide all the spatial and temporal data as input and to obtain corresponding data as output. The coupling of SW and GW system involves a number of specifications. The river reaches where the coupling will take place have been defined in the river model. In the current study, all the major rivers and small streams (locally named as Khals) within the study area have been coupled with GW system. All forms of river-aquifer exchanges and the flooding conditions have also been defined. The flow exchange between the SZ component and the river component is mainly dependent on head difference between river and aquifer and properties of riverbed material such as leakage coefficient. For river-aquifer dynamic flow exchange, leakage coefficients along with the hydraulic conductivity of the SZ are taken into account for most of the river reaches. The developed model is then calibrated for the period of 2000 to 2006 . During calibration phase, overland leakage coefficient, vertical hydraulic conductivity, storage coefficient and river leakage coefficient have been adjusted. Calibration and validation in the model are performed against observed GW level, and three observation wells have been used. In order to increase the reliability of the model, it is verified based on another set of data, which is taken as 2007 to 2009. After successful calibration and validation of the developed model, it is used for GW simulation and resource assessment purposes.

\subsection{Assessment of Groundwater Availability}

GW resource has been estimated based on the well-known GW fluctuation technique (Healy and Cook, 2002) as well as GW balance study on the basis of long-term simulation. The data analysis suggests that only two geological layers exist within $7 \mathrm{~m}$ depth. Saturated thicknesses of these two layers have been calculated based on three considerations.

Case (i): if thickness of 1 st layer exceeds $6 \mathrm{~m}$ or $7 \mathrm{~m}$ depth, entire saturated thickness lies only in 1st layer. Case (ii): if thickness of 1st layer remains above GW level, entire saturated thickness lies only in 2nd layer. Case (iii): if case (i) and case (ii) do not occur, then saturated thickness lies in both 1 st and 2 nd layers. To find out the thickness of 1 st layer within the saturated thickness, simply depth of water table is subtracted from the thickness of 1 st layer. Then, part of 1 st layer within the saturated thickness is subtracted from the entire saturated thickness to find out the thickness of 2nd layer within the saturated thickness.

According to GW level fluctuation method, saturated thickness of first and second layers are multiplied by the corresponding specific yield $\left(S_{Y}\right)$ values and summed up to find out the depth of available water in a model grid. GW storage in volumes is estimated by multiplying the depth of water availability with the area of the grid (volume of water $=$ area $\times \Delta h \times S_{Y}$, where $\Delta h$ is the saturated thickness within $6 \mathrm{~m}$ and $7 \mathrm{~m}$ depths). Now, total available GW resource is estimated based on the number of grids lying within the area under consideration. Finally, GW resource availability has been assessed in design year 2003 at base condition (selected from return period analysis of rainfall)

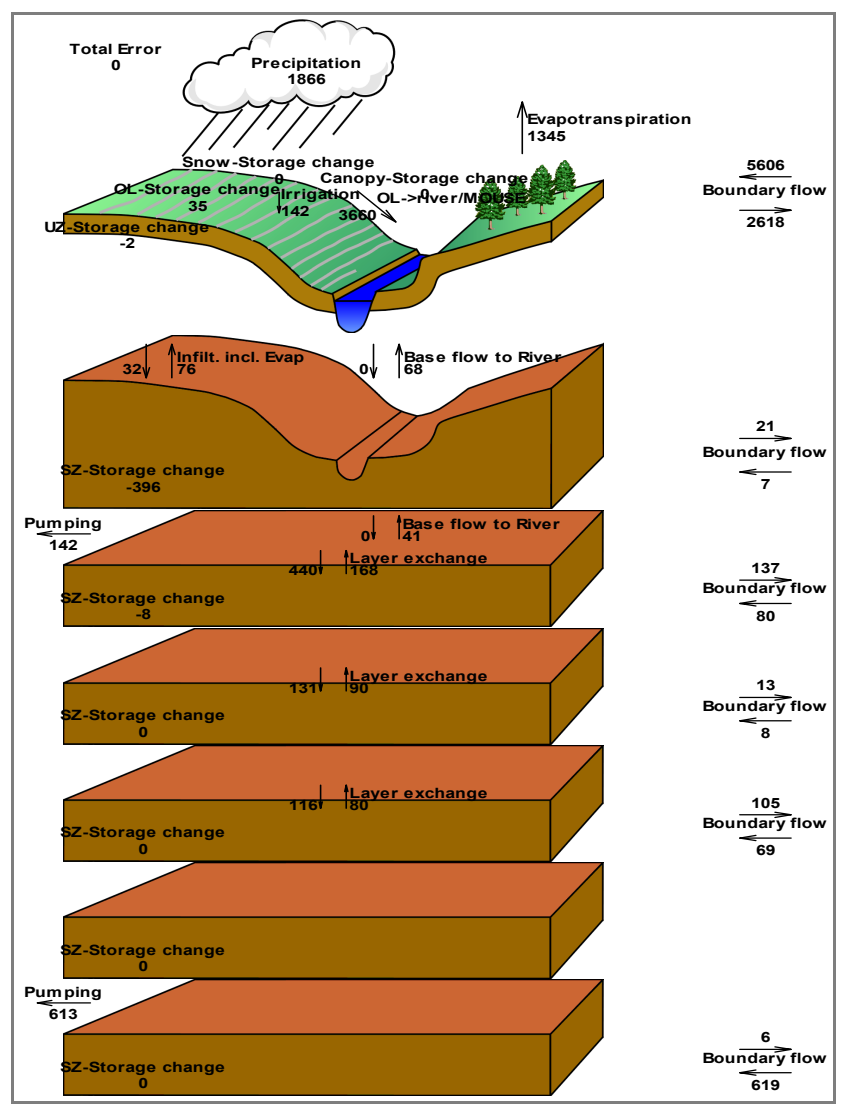

Figure 3. Water balance study at base condition. for two different depths (within $6 \mathrm{~m}$ and $7 \mathrm{~m}$ ) within Rangunia municipality. The result shows that GW resources for these two different depths are found as $8.06 \mathrm{Mm}^{3}$ (million cubic meters) for $6 \mathrm{~m}$ depth and 9.78 $\mathrm{Mm}^{3}$ for $7 \mathrm{~m}$ depth, respectively. In this study, the depth of $6 \mathrm{~m}$ and $7 \mathrm{~m}$ is used for the unconfined aquifer to calculate the available GW resources within the limit of suction mode pump.

For long-term sustainability of the underlying aquifer and sustainable GW resources development in and around the study area, the deeper aquifer has been found more reasonable for water supply. Keeping this in 
Adhikary et al., Identifying safe drinking water source for establishing sustainable urban water supply scheme in Rangunia municipality, Bangladesh

mind, long-term simulation up to design year in 2040 is executed for the developed GW model and a water balance study for the whole model domain has been performed. A trial and error method is applied to find out the maximum abstraction without any negative changes of storage for the deeper aquifer. The net GW recharge for the deeper aquifer is estimated from integrated MIKE-11 and MIKE-SHE simulated output as net recharge $=0 \mathrm{~mm}$ (from upper layer) $-6 \mathrm{~mm}$ (for outflow) $+619 \mathrm{~mm}$ (for inflow) $=613 \mathrm{~mm}$, which mostly comes from the horizontal flow (Figure 3). For this GW recharge amount, corresponding annual aquifer storage volume is estimated by multiplying the aquifer catchment area with the GW recharge and found as $10.57 \mathrm{MCM}$ per annum. The long term simulated hydrographs indicate that the GW level will be lowered down by $0.5 \mathrm{~m}$ after twenty years of $\mathrm{GW}$ use, which is a certain threat to the aquifer sustainability. Therefore, conjunctive use of SW and GW is highly recommended for establishing sustainable water supply scheme. For GW quality assessment, a test well has been drilled and constructed screening the target aquifer but water quality test was not performed yet. Therefore, a survey about GW quality and its acceptance was conducted, which indicates that most $(90 \%)$ of the users are satisfied with the GW quality. Thus, the underlying aquifer of Rangunia municipality can be used as a potential source of water supply for the municipality dwellers. Nevertheless, it is emphasized that detailed water quality analysis program must be carried out and necessary treatment program should be undertaken prior to consumption.

\section{CONCLUSIONS}

In this study, an initial attempt has been made for the assessment of conventional water sources (SW rivers and GW aquifers) in order to identify the potential safe water source for sustainable water supply in the Rangunia municipality. Based on the predicted population and proposed water supply scheme in Rangunia municipality, the projected water demand has been estimated as $9443 \mathrm{~m}^{3} / \mathrm{d}$ in the design year 2040 . The assessment indicates that both SW and GW sources contain sufficient amount of water to meet the demand up to the design year 2040. GW quality in the study is suitable for drinking purposes. SW quality is also within acceptable limit except very few parameters. Therefore, minor treatment is necessary for those parameters to ensure the drinking standard. Finally, the study recommends that conjunctive water use from both SW and GW sources as well as continuous monitoring of the water quality parameters should be carried out for establishing safe and sustainable supply scheme in the Rangunia municipality under Chittagong district in Bangladesh.

\section{ACKNOWLEDGMENTS}

The authors acknowledge the necessary data and modelling supports provided by the Water Resources Planning (WRP) Division of IWM, Municipal Authority of Rangunia and DPHE, Bangladesh for this study.

\section{REFERENCES}

Anderson, M.P., and Woessner, W.W. (1992). Applied Groundwater Modeling: Simulation of Flow and Advective Transport, pp.97-125, New York: Academic Press Inc., USA.

BBS (2005). Statistical Yearbook of Bangladesh-2005, Bangladesh Bureau of Statistics (BBS), Government of Bangladesh.

Chow, V.T., Maidment, D.R., and Mays, L.W. (1988). Applied Hydrology, pp.394-396, McGraw-Hill Inc., New York, USA.

Dasgupta, A., Babel, M.S., Albert, X., and Mark, O. (2005). Water sector of Bangladesh in the context of integrated water resources management: a review. Water Resources Development, 21(2), 385-398.

DHI (1999). MIKE SHE technical reference manual, Danish Hydraulic Institute (DHI), Horsholm, Denmark.

ECR (1997). Environmental conservation rules (ECR) 1997, pp. 178-189, Ministry of Environment and Forest, Government of Bangladesh.

Garcia, A., Sainz, A., Revilla, J.A., Alvarez, C., Juanes, J.A., and Puente, A. (2008). Surface water resources assessment in scarcely gauged basins in the north of Spain. Journal of Hydrology, 356(3-4), 312-326.

Healy, R.W., and Cook, P.G. (2002). Using groundwater levels to estimate recharge. Hydrogeology journal, 10(1), 91-109.

Karim, M.R., and Mohsin, G.M. (2009). Assessment of urban water supply situation: a case study in Khulna City Corporation area. 2nd International Conference on Water \& Flood Management (ICWFM-2009), Dhaka, Bangladesh, 15-17 March, 2009, Vol. 1, pp. 235-242.

Shah, M.A.R., and Khan, M.S.A. (2008). A linear cost minimization model for water supply systems with constrained sources. Journal of Civil Engineering (IEB), 36(1), 13-22.

WaRPO (1999). Bangladesh national water policy draft report, Water Resources Planning Organization (WaRPO), Government of Bangladesh, Dhaka. 